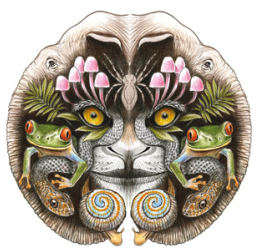

ISSN

Print 0974-7893
Online 0974-7907

OPEN ACCESS

Part of the activities of the Institute of Ayurveda and Integrative Medicine, Bengaluru (formerly known as Foundation for Revitalization of Local Health Traditions (FRLHT)) who's Repository of Medicinal Resources' (RMR) houses over 30,000 voucher specimens comprising around 4,200 species (3100 of them are medicinal), we carried out an extensive botanical survey in Paderu, Narsipatnam and Chintapalli forest ranges (deciduous to moist deciduous forests) in Visakhapatnam District, Andhra Pradesh during September 2011, which resulted in the documentation of 142 taxa of flowering plants. During the process of verification and authentication of the herbarium specimens with the help of Revisions and Floras by Hooker (1872-1897), Gamble (1915-1936), Saxena \& Brahman (1994), Pullaiah (1997), Pullaiah \& Ali Moulali (1997), Pullaiah \& Chennaiah (1997) and Rao \& Kumari (2003, 2008) we found 18 taxa were of distributional importance. Of these, two are new reports to southern India, two new reports to the state of Andhra Pradesh as well as to the Eastern Ghats, seven taxa form additions to the Visakhapatnam District; seven are endemic. The following exotic species namely Clerodendrum aculeatum (L.) Schltr. (Verbenaceae), Stachytarpheta cayennensis (Rich.) Vahl (Verbenaceae), Ipomoea bona-nox L. (Convolvulaceae), Nicandra physalodes (L.) Gaertn. (Solanaceae) and Momordica charantia L. var.

\section{INTERESTING PLANT RECORDS FROM VISAKHAPATNAM DISTRICT, ANDHRA PRADESH, INDIA}

\section{K. Ravikumar ${ }^{1}$, N. Balachandran ${ }^{2}$, S. Noorunnisa Begum $^{3}$, P. Patchaimal ${ }^{4}$, Manoranjan Bhanja ${ }^{5}$ \& \\ K. Lohitasyudu ${ }^{6}$}

1,2,3,4, National Herbarium of Medicinal Plants and Repository of Raw Drug, Institute of Ayurveda and Integrative Medicines (I-AIM), Foundation for Revitalisation of Local Health Traditions (FRLHT), No. 74/2, Jarakabande Kaval, Post Attur, Via. Yelahanka, Bengaluru, Karnataka 560106, India

${ }^{5}$ Additional PCCF, $5^{\text {th }}$ Floor, Aranya Bhavan, Saifabad, Hyderabad, Telangana 500001, India

${ }^{6}$ District Forest Officer, Guntur, Seemandhara 522004, India ${ }^{1}$ k.ravikumar@frlht.org (corresponding author), ${ }^{2}$ nbala_plant@frlht.org,

${ }^{3}$ noorunnisa.begum@frlht.org, ${ }^{4}$ patchaimal@gmail.com, ${ }^{5}$ mrbhanja@gmail.com, ${ }^{6}$ lohit.kadali@gmail.com

muricata (Willd.) Chakrav. (Cucurbitaceae) have also been collected from the study area in wild habitats.

These taxa are presented in alphabetical order with brief botanical descriptions, distribution and important field/taxonomical notes, if any. All the herbarium specimens are deposited at the herbarium of FRLHT (FRLH).

Adenia cardiophylla (Mast.) Engl. in Bot. Jahrb. Syst. 14: 376. 1891; N. Rama Rao et al. in J. Econ. Tax. Bot. 9: 241-245. 1987; Vasudeva Rao in J. Econ. Tax. Bot. 18: 243-244, 1994; Pull. \& Chennaiah, Fl. Andhra Pradesh

DOI: http://dx.doi.org/10.11609/JoTT.03144.6108-21

Editor: B. Ravi Prasad Rao, Sri Krishnadevaraya University, Anantapur, India.

Date of publication: 26 July 2014 (online \& print)

Manuscript details: Ms \# o3144 | Received 30 March 2012 | Final received 07 July 2014 | Finally accepted 10 July 2014

Citation: Ravikumar, K., N. Balachandran, S.N. Begum, P. Patchaimal, M. Bhanja \& K. Lohitasyudu (2014). Interesting plant records from Visakhapatnam District, Andhra Pradesh, India. Journal of Threatened Taxa 6(8): 6108-6121; http://dx.doi.org/10.11609/JoTT.03144.6108-21

Copyright: (c) Ravikumar et al. 2014. Creative Commons Attribution 4.0 International License. JoTT allows unrestricted use of this article in any medium, reproduction and distribution by providing adequate credit to the authors and the source of publication.

Funding: This study is the outcome of botanical survey supported by Ministry of Environment and Forests, Government of India, New Delhi. Sanction number: (13-06/2007-CS.I)

Competing Interest: The authors declare no competing interests.

Acknowledgements: The authors are thankful to the Director, FRLHT and Shri DK Ved, IFS (Retd.) Advisor, FRLHT, Bangalore for providing facilities, constant support and encouragements; the Principal Chief Conservator of Forests, Forest Department, Hyderabad, Andhra Pradesh for granting permission and providing logistic supports during the field survey; the Ministry of Environment and Forests, New Delhi for financial support under "Centre of Excellence" project; the Forest Department officials at Visakhapatnam, Paderu and Narasipatnam ranges for help during field visits.
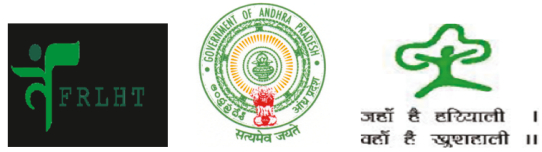


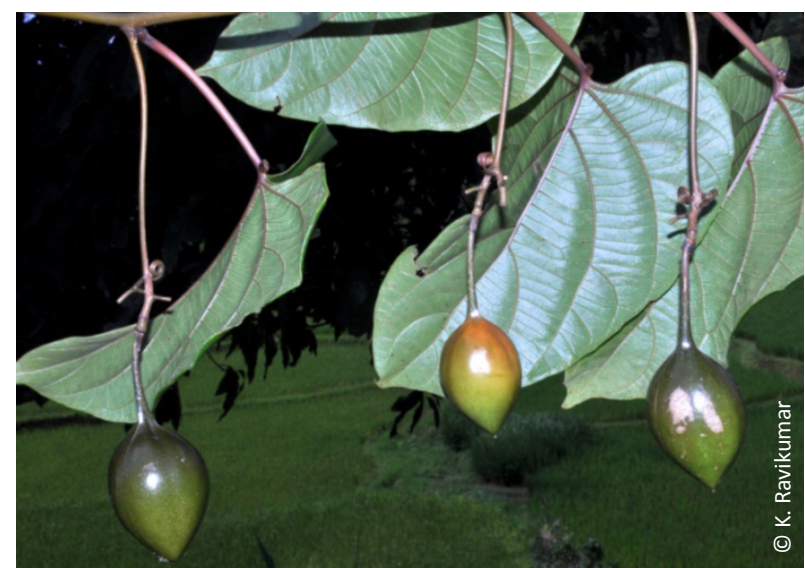

Image 1. Adenia cardiophylla

1: 403. 1997. Modecca cardiophylla Mast. in Hook. f. Fl. Brit. India 2: 602. 1879. (Images 1,2) (Passifloraceae).

Stout climber; stems terete, glabrous. Leaves remote, broadly ovate, deeply cordate at base, acute to shortly acuminate at apex, basally five nerved, secondary veins parallel, ca. $14.5 \times 16 \mathrm{~cm}$; petioles with a sessile gland on either side towards apex. Fruiting peduncles ca. 10 $\mathrm{cm}$ long, terminal part modified into tendril. Fruit a 3-valved capsule, tapering at both ends, ca. $5.7 \times 3 \mathrm{~cm}$, green turning yellow and dark red when ripe, shiny, ovoid; seeds 14-27, flat, pitted, sub-reniform, covered by white aril, attached by 10-12 mm long funicles.

Specimen examined: 111334, 28.ix.2011, (in fruit), elevation at $1200 \mathrm{~m}, \mathrm{G}$. Madugula Village, Chodavaram Taluk, Visakhapatnam District, Andhra Pradesh, India, coll. K. Ravikumar \& N. Balachandran.

Distribution: India (peninsular and northeastern Regions, Andaman and Nicobar Islands), Bhutan, Myanmar, China (Yunnan), Thailand, Cambodia, Laos, Vietnam and Malaysia.

Notes: In India this species has so far been known from northeastern states such as Sikkim, Assam Meghalaya (Khasi Hills) and Andaman \& Nicobar Islands. Rama Rao et al. (1987) collected this species from Rampa Hills Madhiveedu, East Godavari District, Andhra Pradesh and reported it as a new record to southern India. They further stated that it is rare on the bushes near streams in mixed forests; at an altitude between 1000-2000 m.

The present collection from Visakhapatnam extends its distribution further towards north of its earlier record from East Godavari District and also forms first report to the district. Only three plants have been noticed climbing on bushes along the road side. It is associated with Sterculia villosa Roxb. Cassia fistula L. and Thysanolaena latifolia (Roxb. ex Hornem.) Honda.

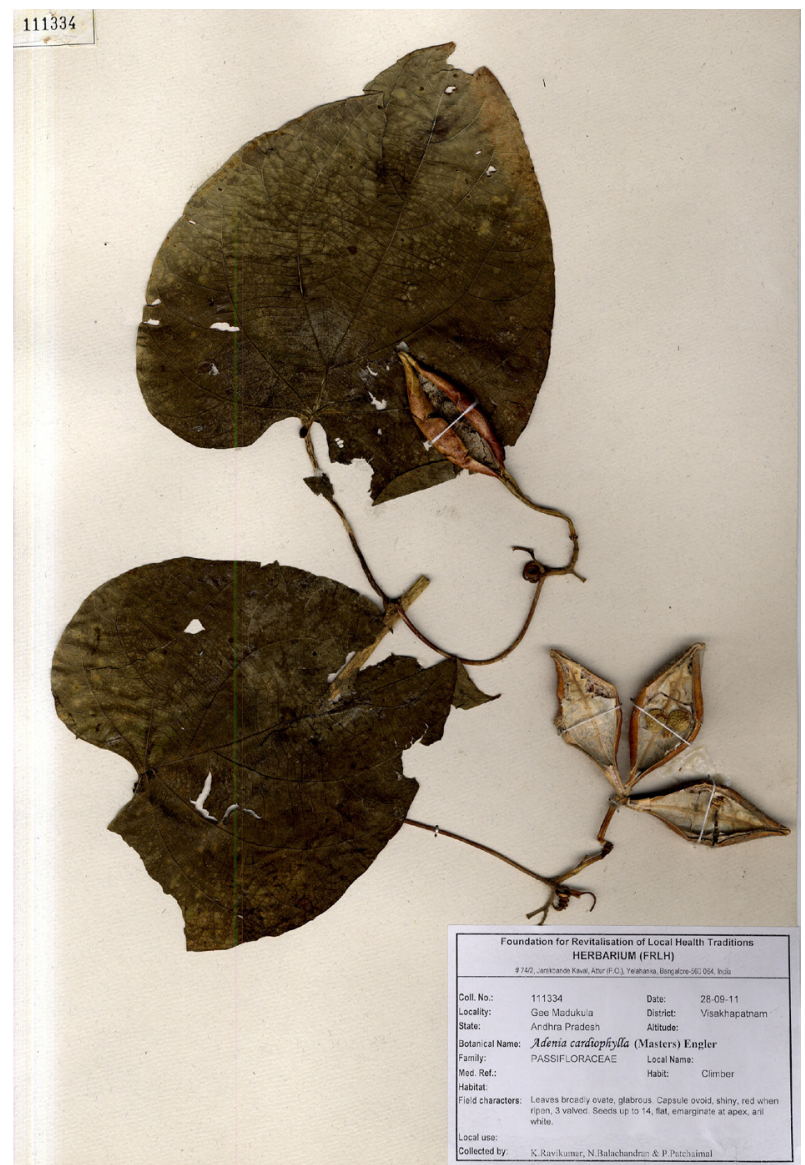

Image 2. Herbarium of Adenia cardiophylla

Destruction of the nearby forest areas for cultivation in future is a serious threat to the existence of this species.

Amorphophallus bulbifer (Roxb.) Blume in Rumphia 1:148.1837; Hook. f., Fl. Brit. India 6: 515.1893; C.E.C. Fisch. in Fl. Pres. Madras 3: 1598 (1107). 1931; Pull., Fl. Andhra Pradesh 3: 1022. 1997; R.S. Rao, Fl. East Godavari. 719. 1999. Arum bulbiferum Roxb., Fl. Ind.ed. 1832. 3: 510. 1832. (Image 3) (Araceae).

Erect herb. Tuber globose. Leaves up to $85 \mathrm{~cm}$ in diam. 3-fid, decompound; odd pinnae up to $45 \mathrm{~cm}$, obovatelanceolate; leaflets oblanceolate-oblong, sessile, apex long acuminate-caudate, lower leaflets smaller, upper longer, $5.5 \times 2.5$ to $21 \times 7.5 \mathrm{~cm}$; with brownish, depressed globose, bulbilliferous at the axial of every fork; petioles up to $1.2 \mathrm{~m}$ long, mottled with brown, white and green spots and streaks.

Specimen examined: 111326, 28.ix.2011, (in vegetative form), elevation at $1128 \mathrm{~m}$, Paderu Taluk, Minumuluru, Visakhapatnam District, Andhra Pradesh, India, coll. K. Ravikumar \& N. Balachandran.

Distribution: India (northeastern India and the 


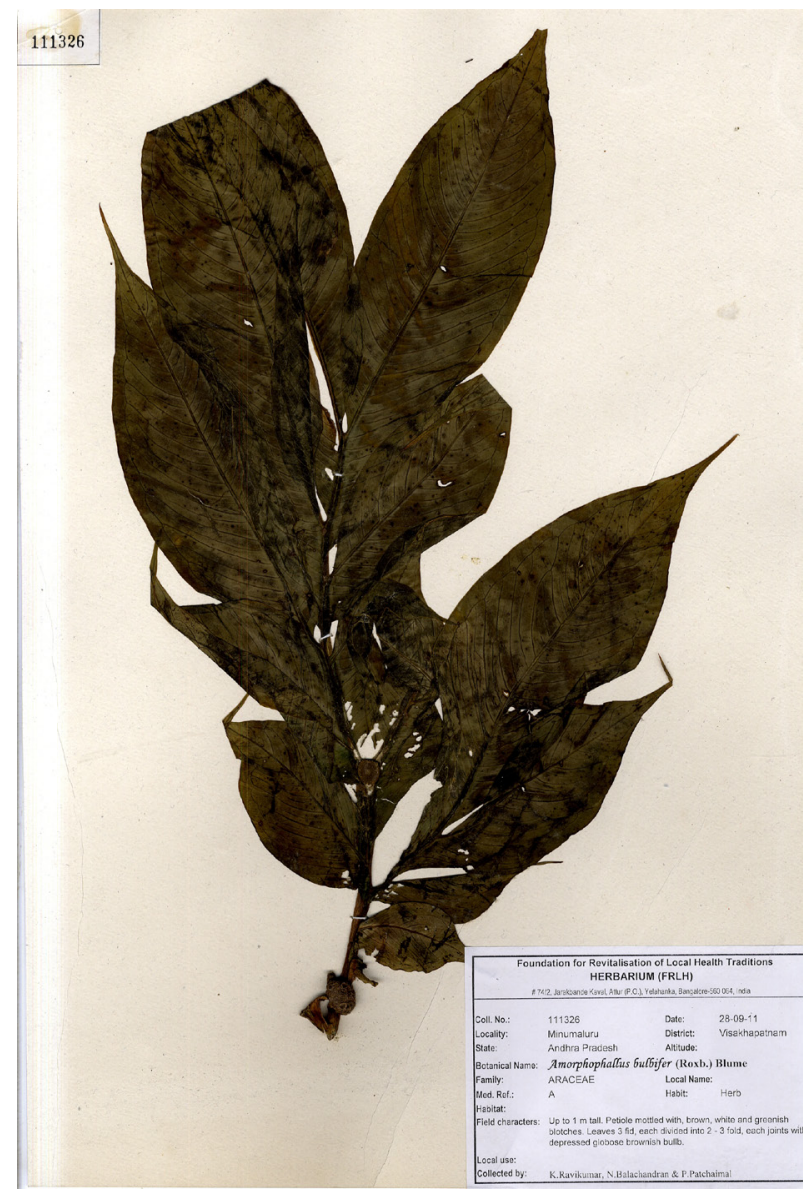

Image 3. Herbarium of Amorphophallus bulbifer

Himalayan region) and Myanmar.

Notes: This plant has been represented by a single collection at CAL for the State of Andhra Pradesh from Devarakonda, the hills of East Godavari District. The present collection could be the second collection for Andhra Pradesh and forms as a new report to Visakhapatnam District.

Ardisia depressa C. B. Clarke in Hook. f., FI. Brit. India 3: 522.1882; Gamble, Fl. Madras 2: 755.1921; Haines, Bot. Bihar \& Orissa 509. 1922; Haines, Suppl. Bot. Bihar \& Orissa 84. 1950; Pull. \& Moulali, FI. Andhra Pradesh 2:547.1997; Subba Rao \& Kumari, Fl. Visakhapatnam 1: 473. 2003. (Image 4) (Myrsinaceae).

Shrub, up to $3 \mathrm{~m}$ tall; branchlets terete, glabrous. Leaves elliptic-lanceolate, ca. $10 \times 2.5 \mathrm{~cm}$, glabrous with punctuate glands on both sides; lateral nerves obscure. Flowers in 1-3-flowered umbels, dull pink, ca. $1 \mathrm{~cm}$ across. Drupes globose, shiny, ca. $6 \mathrm{~mm}$ across, ripening black.

Specimen examined: 110884, 27.ix.2011, (in

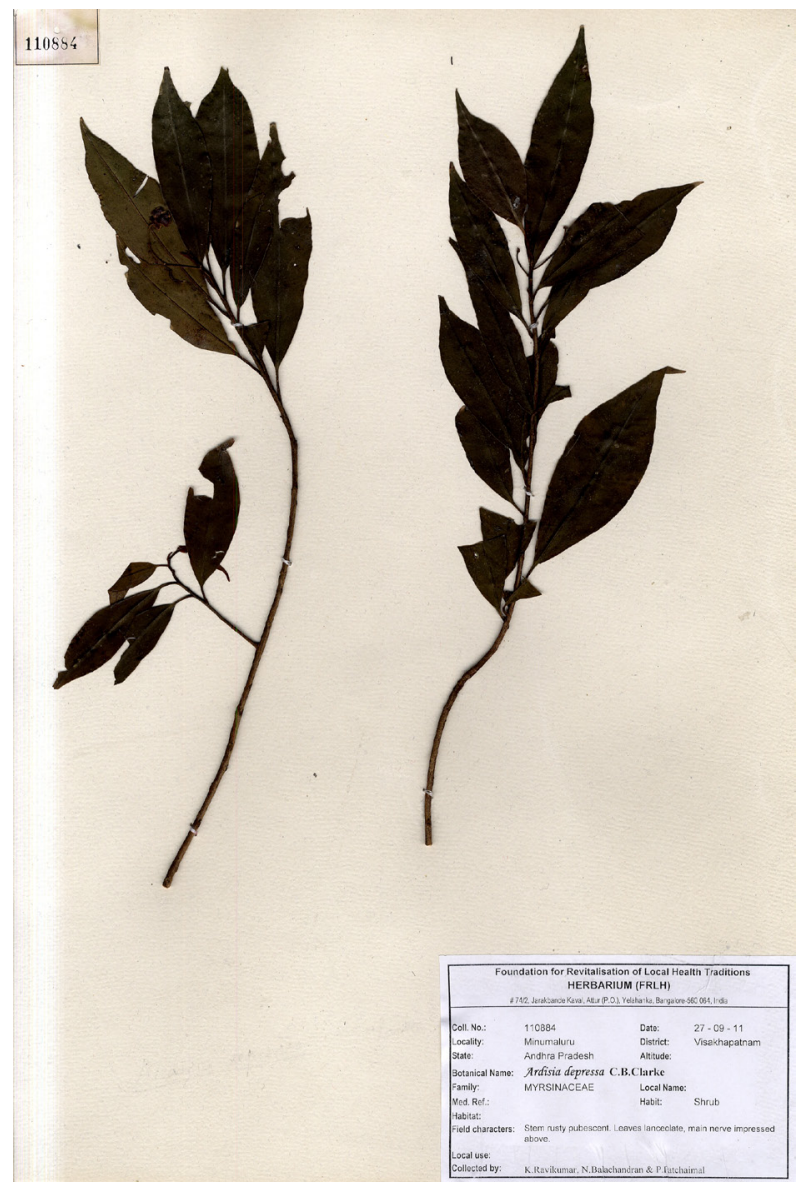

Image 4. Herbarium of Ardisia depressa

flowers and fruits), elevation at $1130 \mathrm{~m}$, Paderu Taluk, Minumuluru, Visakhapatnam District, Andhra Pradesh, India, coll. K. Ravikumar \& N. Balachandran.

Distribution: India (Andhra Pradesh, Assam, Bihar, Kerala, Meghalaya, Orissa and Sikkim) and Myanmar.

Notes: The distribution of this species in India is restricted to northeastern states (Sikkim, Meghalaya and Assam) to Bihar, Orissa and Andhra Pradesh. In Andhra Pradesh, it has been recorded only in Visakhapatnam District. The distribution of this species is unique and the occurrence is restricted to the highly fragile ecosystem in the study area which needs immediate conservation measures.

Aspidopterys indica (Willd.) W.Theob. Burmah ed. 3, 2: 599 1883; Hochr. in Bull. Inst. Bot. Buitenzorg 19. 45. 1904; Pullaiah \& Chennaiah, Fl. Andhra Pradesh 1: 163.1997; R.C. Srivast. in Hajra et al., Fl. India 4: 8. 1997. Triopterys indica Willd. Sp. PI., ed. 4 , 2(1): 744. 1799 Aspidopterys roxburghiana A. Juss. in Ann. Sci. Nat. Bot. Ser. 2. 13: 267. 1840; Hook. f., Fl. Brit. India 1: 


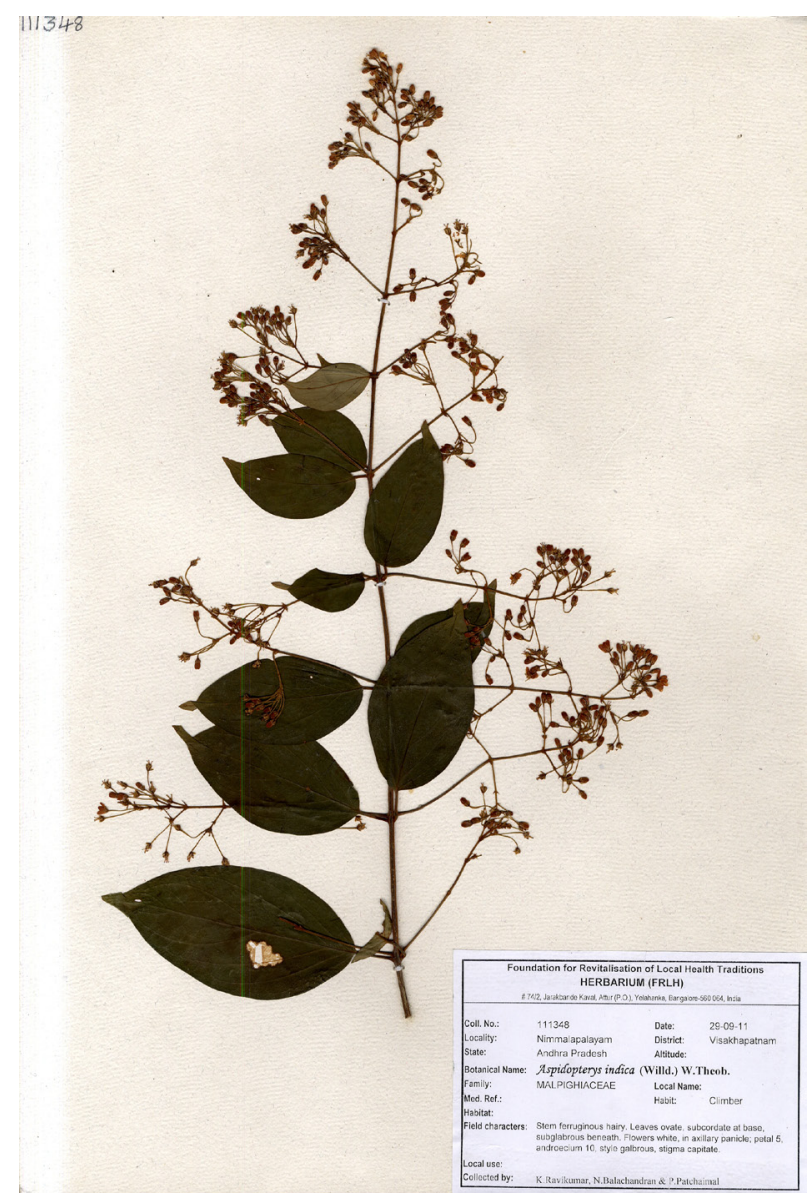

Image 5. Herbarium of Aspidopterys indica

420. 1874; Gamble, Fl. Madras 1: 129. 1915. (Image 5) (Malphigiaceae)

Slender climber; young stem ferruginous hairy. Leaves ovate-elliptic, ca. $12 \times 8 \mathrm{~cm}$, cordate to subcordate at base, acute-acuminate at apex, glabrous above, pubescent along nerves beneath. Inflorescense axillary, corymbose panicles, ca. $12 \mathrm{~cm}$ long, rusty pubescent. Flowers white, 5-6 mm across; calyx and corolla 5-partite, pubescent outside; stamens 10; styles 3, glabrous, unequal; stigma capitate.

Specimen examined: 111348, 29.ix.2011, (in flower), elevation at $422 \mathrm{~m}$, Nimmalapalayam Village, Narasipatnam Range, Visakhapatnam District, Andhra Pradesh, India, coll. K. Ravikumar \& N. Balachandran.

Distribution: India (Andhra Pradesh, Assam, Madhya Pradesh, Meghalaya, Nagaland, Orissa, and Tamil Nadu) and Myanmar.

Notes: Hooker (1872-1897) recorded the distribution of this species in India and "Birma (Myanmar), Saluen River", whereas in Flora of India (1997) it is stated as "Endemic" to India. The present collection forms a new report to Visakhapatnam District.

Cassine paniculata (Wight \& Arn.) Lobr.-Callen in Adansonia (ser. 2) 15:220. 1975; Kostermans, A.J.G.H. Gard. Bull. Singapore 39: 178. 1986; Nair \& Henry. Fl. Tami Nadu 1: 72. 1983; K. Ramamurthy in N.P. Singh et al. (eds.) Fl. India 5: 83. 2000. Elaeodendron paniculatum Wight \& Arn., Prodr. Fl. Ind. 157. 1834; Gamble, Fl. Madras 1:212. 1918; Matthew, III. Fl. Palni Hills t. 119. 1996. (Images 6,7) (Celastraceae).

Tree up to $10 \mathrm{~m}$ tall. Leaves elliptic-lanceolate, ca. $10 \times 4 \mathrm{~cm}$, oblique at base, irregularly crenate along margins. Inflorescense a dichasial corymbose cymes, usually in upper leaf axils; peduncles up to $6 \mathrm{~cm}$ long. Flowers ca. $7 \mathrm{~mm}$ across, greenish-yellow; petals spathulate.

Specimen examined: 111386, 30.ix.2011, (in flower), elevation at 550m, Rompulu Ghat Road (PedavalasaRinthada route), Visakhapatnam District, Andhra Pradesh, India, coll. K. Ravikumar \& N. Balachandran.

Distribution: India (Karnataka, Kerala and Tamil Nadu), Sri Lanka and Malaysia.

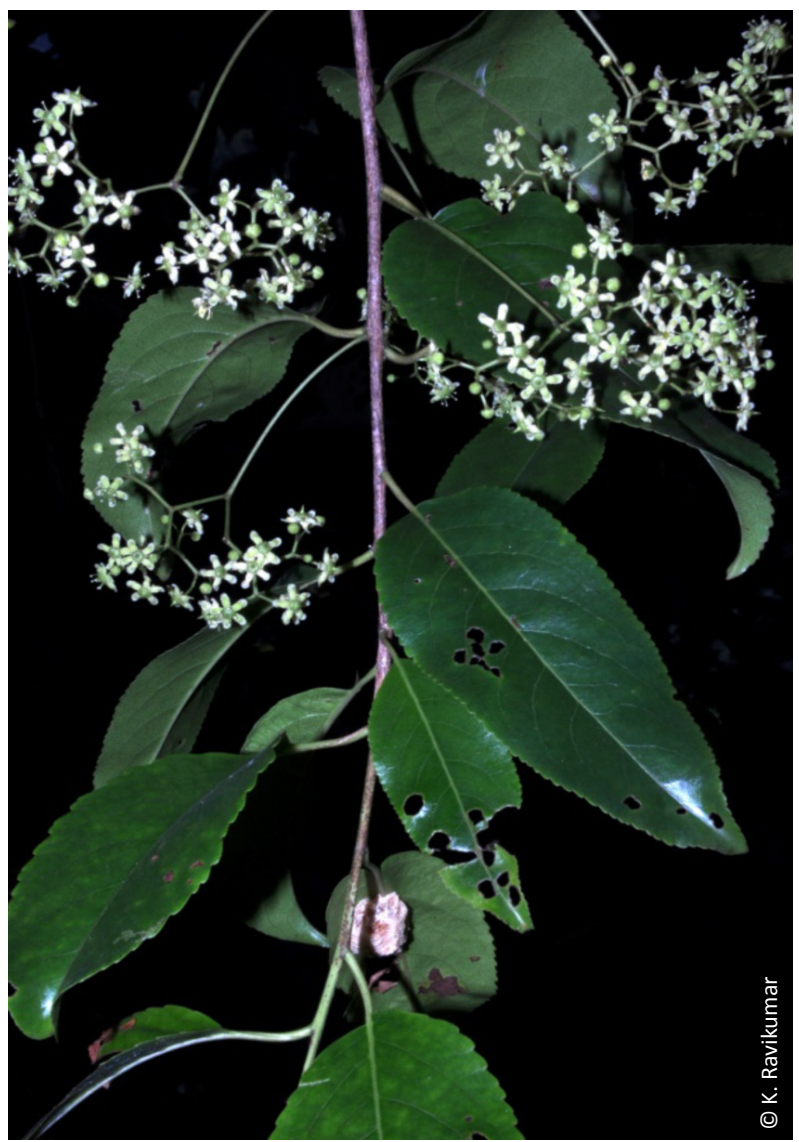

Image 6. Cassine paniculata 


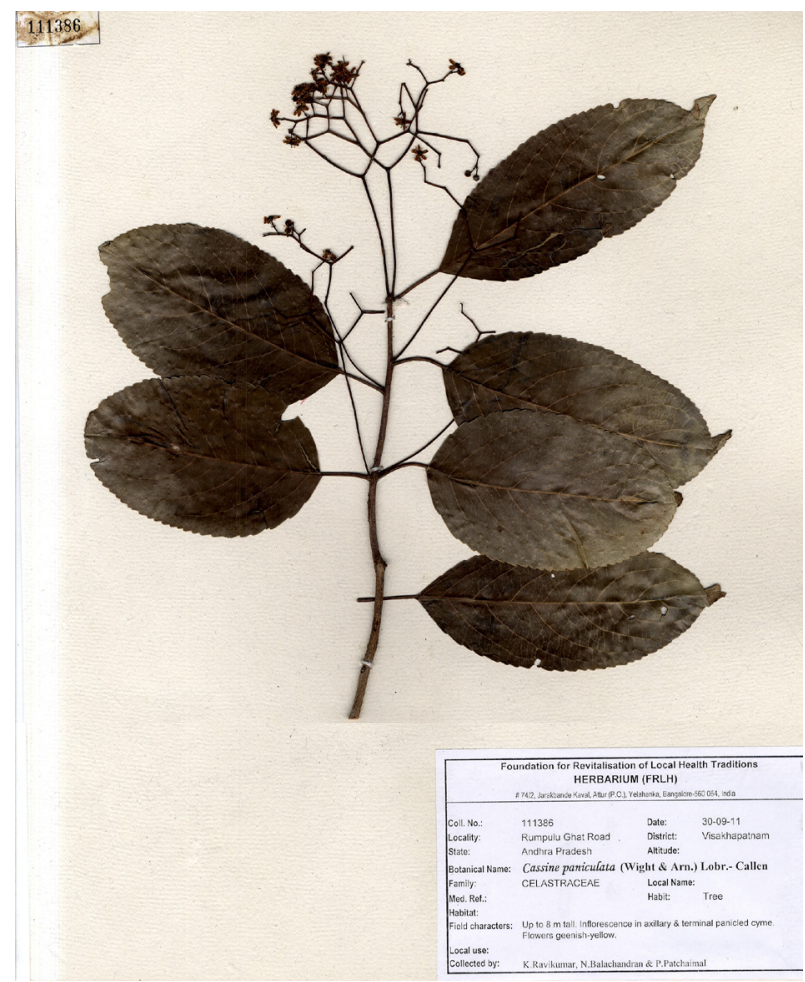

Image 7. Herbarium of Cassine paniculata

Notes: In India, so far this species has been reported only from the Western Ghats of Kerala, Karnataka and Tamil Nadu. The present collection from Andhra Pradesh not only forms a new report for the state but also for the Eastern Ghats.

Cleidion javanicum Bl., Bijdr. 613. 1826; Hook.f., Fl. Brit. India 5: 444. 1887; Airy-Shaw in Kew Bull. 36: 279, f. 3D. 1981; N.P. Balakr. \& Chakrab., Euphorbicaeae in India 134. 2007. (Images 8,9) (Euphorbiaceae).

Tree, up to $10 \mathrm{~m}$ tall; bark ashy brown, smooth. Leaves alternate, elliptic-oblanceolate, up to $16 \times 6.5 \mathrm{~cm}$, cuneate at base, abruptly acuminate at apex, distantly crenate, glabrous above, domatia along the nerve axis beneath; petioles ca. $10 \mathrm{~cm}$ long. Female flowers solitary, axillary; peduncles ca. $7 \mathrm{~cm}$ long, thickened above; styles 2 , each divided into 2 filiform arms. Capsules ca. $3 \mathrm{~cm}$ across, usually didymous.

Specimen examined: 110877, 27.ix.2011, (in flowers), elevation at $1120 \mathrm{~m}$, Minumuluru, Paderu Taluk, Visakhapatnam District, Andhra Pradesh, India, coll. K. Ravikumar \& N. Balachandran.

Distribution: India (Arunachal Pradesh, Assam, Bihar, Karnataka, Kerala, Maharashtra, Manipur, Meghalaya, Mizoram, Nagaland, Sikkim, Tamilnadu, Tripura, and A \& N Islands), Sri Lanka, Nepal, Bhutan, Myanmar, China,

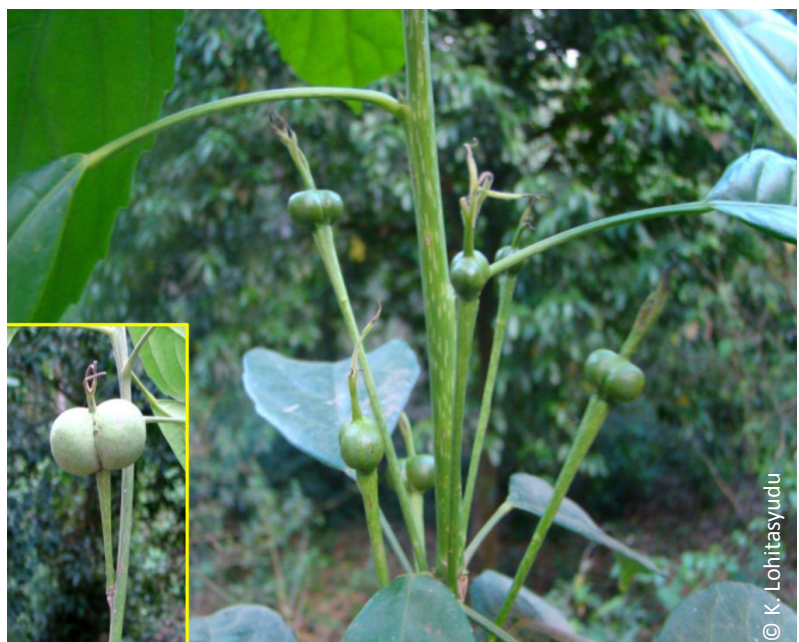

Image 8. Cleidion javanicum

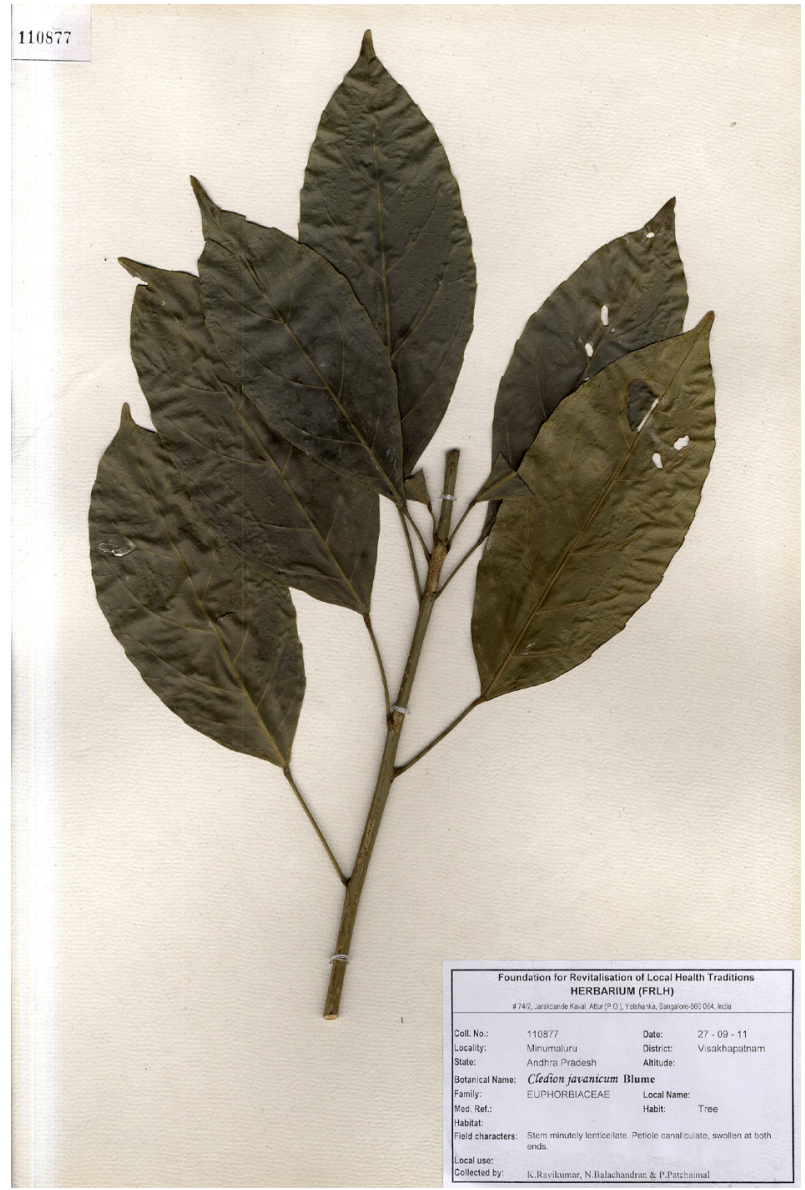

Image 9. Herbarium of Cledion javanicum

Thailand, Malaysia and Australia.

Notes: In India, this species has so far been reported in the northeastern states, throughout the Western Ghats and the Andaman \& Nicobar Islands (Balakrishnan 
\& Chakrabarthy 2007). The present collection forms a new report for Andhra Pradesh state as well as the Eastern Ghats.

Cynanchum corymbosum Wight, Contrib. Bot. India 56. 1834; Hook. f., Fl. Brit. India 4: 24. 1883; Kanjilal et al. FI. Assam 3: 286. 1939; Deb, Fl. Tripura 2: 31. 1983; Jagtap \& Singh in Fasc. Fl. India 24. 19. 1999. Cynoctonum corymbosum (Wight) Decne. in DC., Prodr. 8. 528. 1844. (Images 10,11,12). (Apocynaceae).

Slender, extensive climber; stems terete, pubescent along two lines; latex white, thick. Stipules foliaceous, reniform, ca. $1 \times 1.3 \mathrm{~cm}$. Leaves ovate-cordate, up to $20 \times 12 \mathrm{~cm}$, acuminate-caudate at apex, cordate at base with incision up to $2 \mathrm{~cm}$ deep looking like an inverted "U", glabrous above, glaucous beneath, with a distinct sessile brown gland at the base of the lamina; petioles ribbed, terete, ca. $4 \mathrm{~cm}$ long. Flowers in corymbose cymes, pubescent, white, fragrant; calyx-lobes 5, ovate, short, ca. 1mm long; corolla-lobes 5, linear-lanceolate, ca. 6x1 mm, greenish yellow; corona tubular, erect,
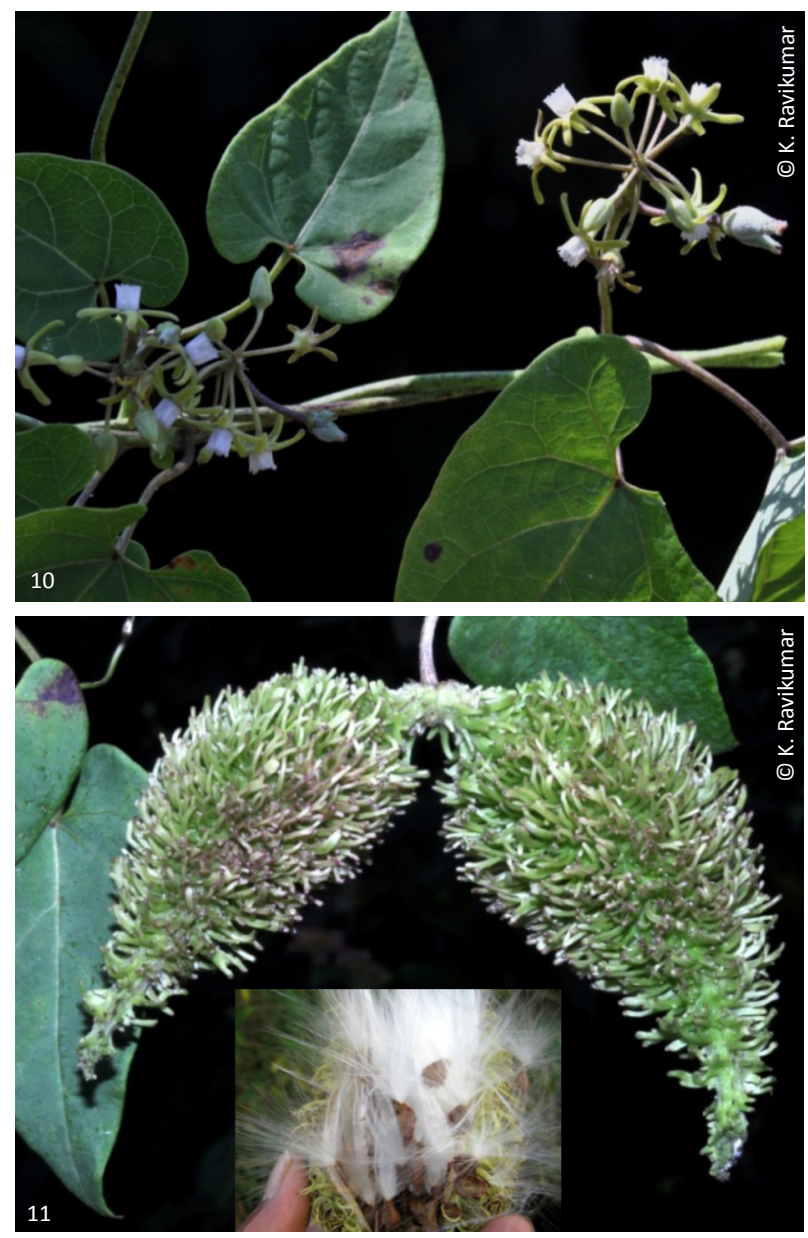

Images 10 \& 11. Cynanchum corymbosum
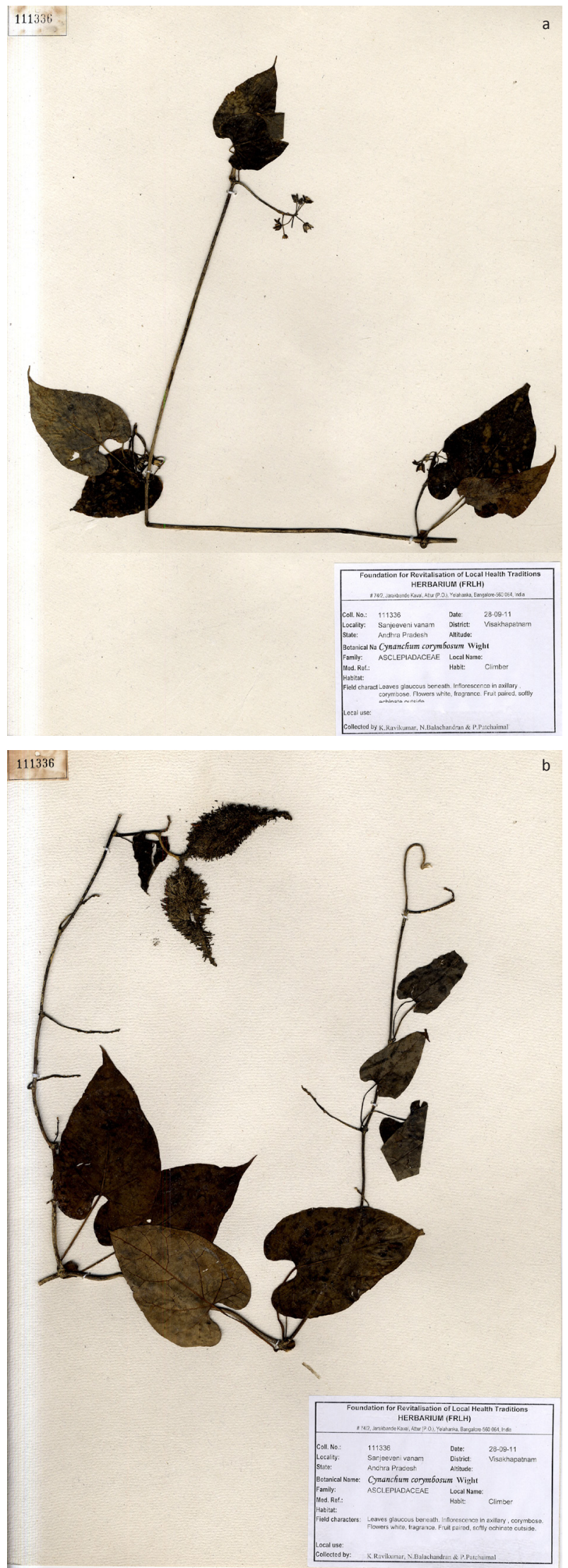

Image 12. Herbarium of Cynanchum corymbosum (a) flowers; (b) fruits 
white. Follicles generally in pairs, rarely single, ellipticlanceolate, ca. $10 \times 5 \mathrm{~cm}$, clothed with long dense fleshy spines, echinations dull pink when young; seeds many, ovate, brown with silky white coma.

Specimen examined: 111336, 28.ix.2011, (flowers and fruits), elevation at $1045 \mathrm{~m}$, Sanjivini Vanam, Paderu Taluk, Visakhapatnam District, Andhra Pradesh, India, coll. K. Ravikumar \& N. Balachandran.

Distribution: India (Arunachal Pradesh, Assam, Manipur, Meghalaya, Nicobar, Sikkim, Tripura), Cambodia, Laos, Malaysia, Myanmar and Vietnam.

Note: In India, this plant has so far been reported only from the northeastern states (Arunachal Pradesh, Assam, Manipur, Meghalaya, Sikkim and Tripura) and Nicobar Islands. The present collection forms a new report to southern India. Only one plant has been seen growing along the side of a stream and found associated with Hedychium coronarium J.Koenig, Mimosa pudica L., Dioscorea tomentosa J.Koenig ex Spreng, Cyclea peltata (Lam.) Hook. f. \& Thomson, Ardisia solanacea (Poir.)

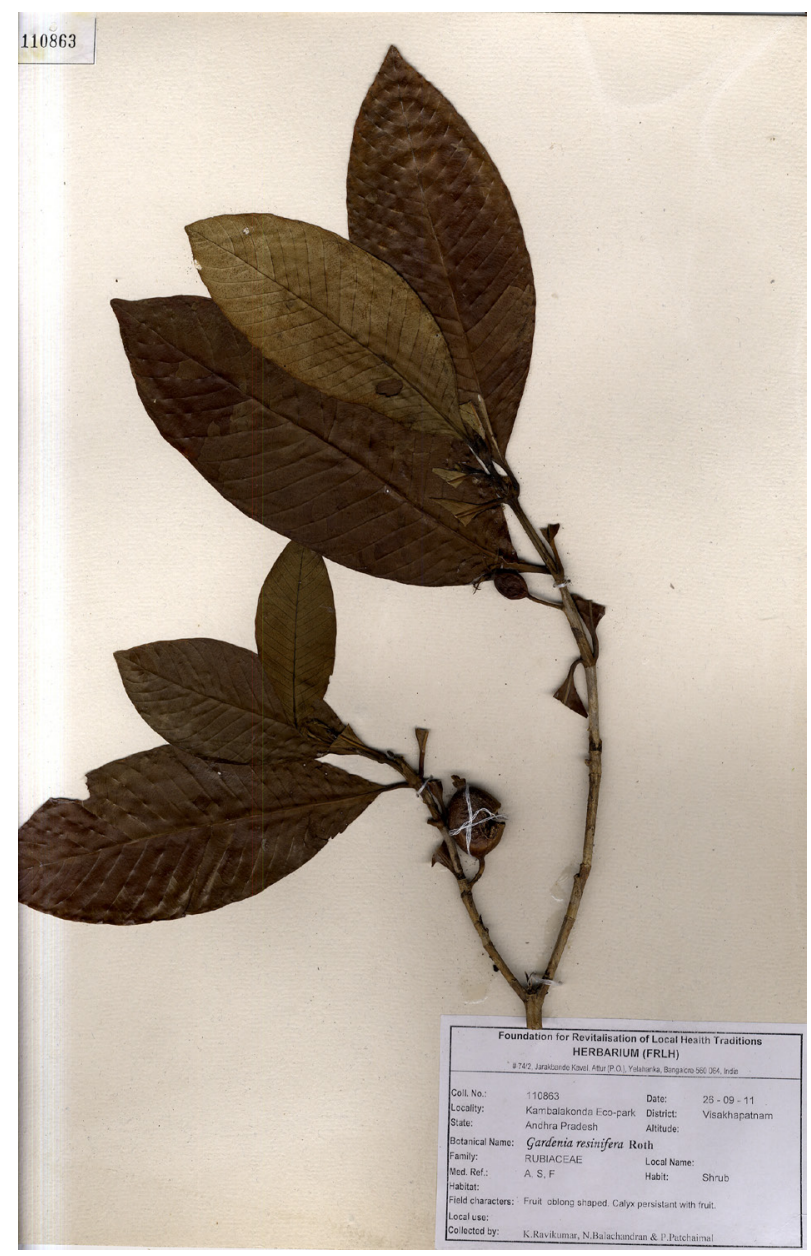

Image 13. Herbarium of Gardenia resinifera
Roxb., Neolitsea sp., Streblus taxoides (Roth) Kurz, etc.

Gardenia resinifera Roth, Nov. PI. Sp. 150. 1821; Pull. \& Moulali, Fl. Andhra Pradesh 2: 475. 1997. (Image 13) (Rubiaceae).

Large shrub, up to $4 \mathrm{~m}$ high; bark greenish-grey; branchlets terete. Leaves oblanceolate-elliptic, ca. $16 \times 6.5 \mathrm{~cm}$, shining, with prominent parallel nerves; young buds with yellow resin. Fruits axillary, solitary, ellipsoid ca. $2.5 \times 1.5 \mathrm{~cm}$, with persistent calyx-cup consisting long, acuminate teeth.

Distribution: India (Western peninsula and East Coast of Andhra Pradesh), Bangladesh and Myanmar.

Specimen examined: 110863, 26.ix.2011, (in fruits), elevation at 30m, Kambala Konda Ecopark, Visakhapatnam District, Andhra Pradesh, India, coll. K. Ravikumar \& N. Balachandran.

Notes: This plant is considered common in dry deciduous forests in most districts of Andhra Pradesh (Pullaiah \& Moulali 1997), however there is no collection from Visakhapatnam District (Rao \& Kumarai 2008) and therefore, it is an addition to that District.

Indigofera zollingeriana Miq., Fl. Ind. Bat. 1, 1: 310. 1885; Sanjappa, Legumes Ind. 198. 1992 \& in Hajra et al. Fasc. Fl. India 21. 159. 1995. Indigofera teysmanii Miq., FI. Ind. Bat. 1: 108 3. 1855; C.J. Saldanha \& G. Singh in C.J. Saldanha, Fl. Karnataka 1: 474. 1984. Indigofera benthamiana Hance in Ann. Sci. Nat. Bot. 4, 18: 219. 1862; Ravi in J. Bombay Nat. Hist. Soc. 73: 242. 1976. (Image 14) (Fabaceae-Papilionoideae).

Tree up to $8 \mathrm{~m}$ tall; branches horizontal and drooping. Leaves odd pinnate, ca. $25 \times 12 \mathrm{~cm}$; leaflets lanceolate, ca. $6.5 \times 1.2 \mathrm{~cm}$, obtuse at base, acute-acuminate at apex, Inflorescence racemose, 10-21 cm long, perpendicular to the branch. Flower pinkish red, ca. $1 \mathrm{~cm}$ long, bud ferruginous-brown outside. Pods ca. $4 \times 0.3 \mathrm{~cm}$, densely packed in lower part of the peduncle and sparse in upper part, straight, cylindrical with persistent thickened stylar base, with brownish pubescent thick sutures; seeds discoid, brown.

Specimen examined: 111328, 28.ix.2011, (in flowers and fruits), elevation at $1100 \mathrm{~m}$, near Paderu, Visakhapatnam District, Andhra Pradesh, India, coll. K. Ravikumar \& N. Balachandran.

Distribution: India (cultivated), China, Thailand, Laos, Vietnam, Taiwan, Malaysia; cultivated in many countries of Asia.

Note: Generally this plant is cultivated in coffee and tea plantations and coconut groves. Occasionally it is found as an escape in Andhra Pradesh, Gujarat, 


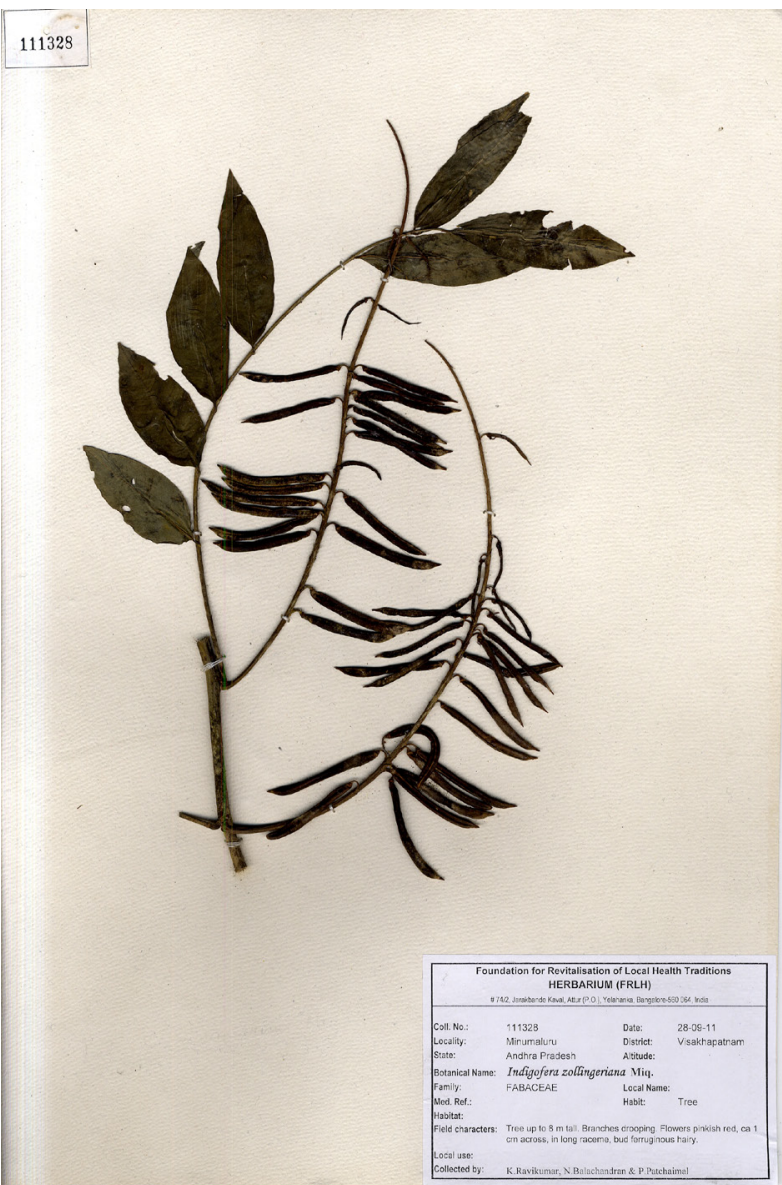

Image 14. Herbarium of Indigofera zollingeriana

Karnataka, Kerala, Tamil Nadu, Andaman \& Nicobar Islands, W. Bengal (Sanjappa 1995), but so far no records from Andhra Pradesh.

Lasianthus truncatus Bedd., Ic. PI. Ind. Or. t. 9. 1874; Hook.f., FI. Brit. India 3: 189.1880; Gamble, Fl.. Madras 2: 647. 1921; Deb \& M. Gangop. in J. Econ. Taxon. Bot. 15(2): 265-308. 1991; H.O. Saxena \& Brahmam, Fl. Orissa 2: 850.1995; Pull. \& Moulali, FI. Andhra Pradesh 2: 487. 1997. (Images 15,16) (Rubiaceae).

Shrub, up to $2 \mathrm{~m}$ high; branchlets puberulous. Leaves opposite, superimposed, narrowly lanceolate, ca. 15×3.5 $\mathrm{cm}$, coriaceous, cuneate at base, acuminate-caudate at apex; lateral nerves prominent on both sides, about eight pairs. Flowers in sessile axillary clusters, ca. $6 \mathrm{~mm}$ across, white. Drupes subglobose to ovoid, ca. 9x6 mm, glabrous, shiny, with a crown of calyx-cup, turbinate, dark blue when ripe.

Specimen examined: 110883, 27.ix.2011, (in flowers and fruits), elevation at $1130 \mathrm{~m}$, Minumuluru, Paderu Taluk, Visakhapatnam District, Andhra Pradesh, India,

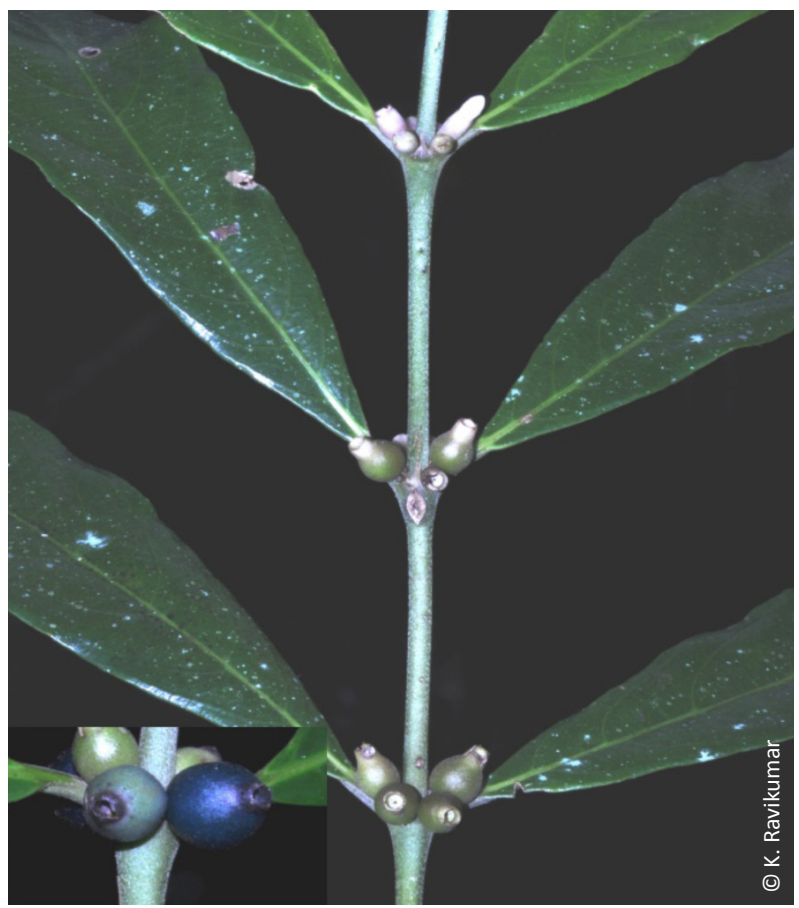

Image 15. Lasianthus truncatus

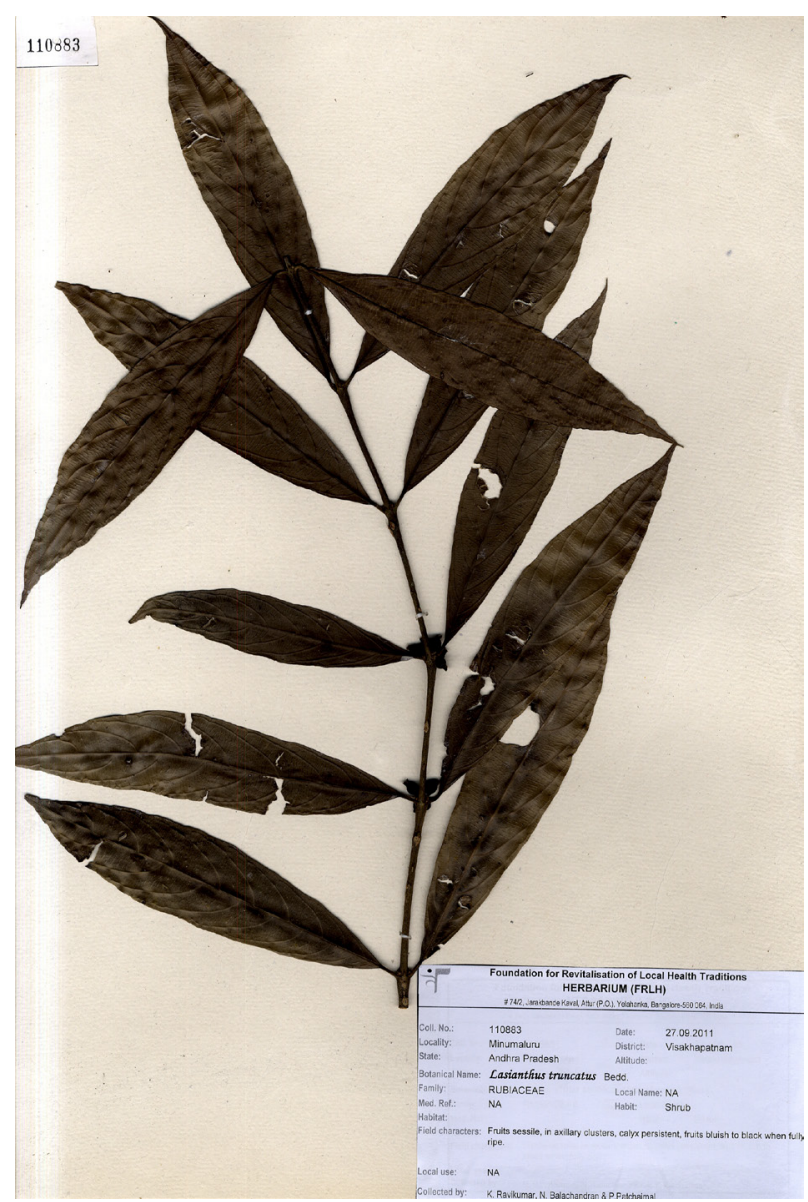

Image 16. Herbarium of Lasianthus truncatus 
coll. K. Ravikumar \& N. Balachandran.

Distribution: India (Eastern Ghats), Endemic

Notes: Hooker (1872-1897) while providing the distribution of this species quotes Beddome's collection from Mahendragiri Hills of Ganjam, Orissa at $1371 \mathrm{~m}$, and Gamble (1921) refers the collection by A.W. Lushington from the hills of Visakhapatnam at $1066 \mathrm{~m}$. Ours is the fresh collection after almost a century. From this, it is evident that this species is very rare.

The present collection was made in a small moist forest patch surrounded by an abandoned estate. The forest patch was about $200 \mathrm{~m}$ long with a perennial streamlet. The biotic pressures such as timber extraction, fuel wood collection and cattle grazing were observed in this area which eventually poses a serious threat to this patchy ecosystem along with a few interesting floral elements. Only nine plants have been counted in this fragile ecosystem and this species is found growing along with Lasiococca comberi Haines, Chassalia ophioxyloides (Wall.) Craib, Sarcococca saligna Mull.Arg. and Amischotolype mollissima (Blume) Hassk.

Nervilia aragoana Comm. ex Gaudich. in Freycinet, Voy. Uranie t. 15. 1827 \& 422. 1829; Fischer, in Gamble Fl. Madras 3: 1459. 1928; Pull. Fl. Andhra Pradesh 3. 950. 1997; R.S. Rao, Fl. East Godavari Dt. 665. 1999. (Image 17) (Orchidaceae).

Terrestrial, tuberous herb; tubers depressed globose, ca. $1.6 \times 1.5 \mathrm{~cm}$. Leaves single, ca. $10 \times 12 \mathrm{~cm}$, cordate to ovate, cordate at base, acuminate at apex, wavy along margins, about 15-nerved from base, seven pair of nerves on either side intersecting the main nerves ending with in curved lobe along the margin; petioles up to $21 \mathrm{~cm}$ long.

Specimen examined: 111338, 28.ix.2011, (in vegetative form), elevation at $1100 \mathrm{~m}$, Sanjivani Vanam, Visakhapatnam District, Andhra Pradesh, India, coll. K. Ravikumar \& N. Balachandran.

Distribution: India (Himalayas, southern India), Bangladesh, Bhutan, Indonesia, Japan, Laos, Malaysia, Myanmar, Nepal, New Guinea, Philippines, Thailand, Vietnam, Australia and Pacific Islands.

Notes: Though this species is reported to be frequent under growth in moist forests of Rampa Hills, in the adjacent East Godavari District (Rao et al. 1999), in the present area only a few individuals have been noticed, and this species also forms a new report for Visakhapatnam District. This species has been assessed as a Red Listed Medicinal plant by Ravikumar \& Ved (2000).

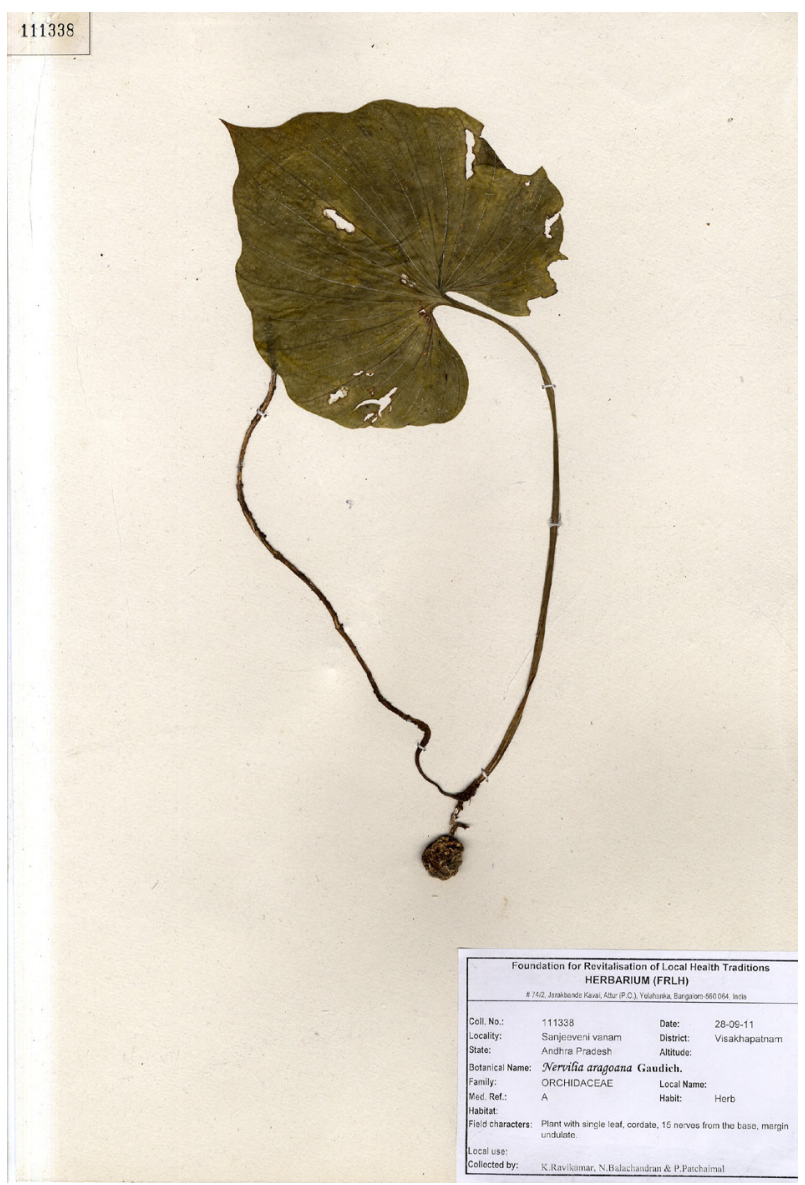

Image 17. Herbarium of Nervilia aragoana

Ormocarpum cochinchinense (Lour.) Merr. in Philipp. J. Sci. 5: 76.1910; Pull. \& Chennaiah, Fl. Andhra Pradesh 1: 303. 1997. Diphaca cochinchinensis Lour. Fl. Cochinch. 454. 1790. Ormocarpum sennoides (Willd.) DC., Prodr. 2: 315.1825; Wight, Icon. PI. Ind. Or. t. 297. 1840; Hook. f. Fl. Brit. India 2: 152. 1876; Gamble, Fl. Madras 1: 332. 1918. (Fabaceae-Papilionoideae).

Shrubs, up to $2 \mathrm{~m}$ high; branchlets glabrescent. Leaves odd pinnate; leaflets about six pairs, alternate to sub-opposite, obovate, ca. $1.5 \times 1 \mathrm{~cm}$, cuneate at base, obtuse to emarginate at apex, chartaceous; petioles minutely prickled.

Distribution: India (Peninsular) and Sri Lanka.

Specimen examined: 116947, 26.ix.2011, (in vegetative form), at $30 \mathrm{~m}$, Kambala Konda Ecopark, Visakhapatnam District, Andhra Pradesh, India, coll. K. Ravikumar \& N. Balachandran.

Notes: Rao \& Kumari (2003) have not reported this species in their Flora of Visakhapatnam and hence, it is an addition to that District.

Pholidota pallida Lindl., Edw. Bot. Reg. 21: subt. 1777. 
1836; Hook., Exot. Fl. Sub t. 138. 1825; Hook. f., Fl. Brit. India 5: 845.1890; Haines, Bot. Bihar Orissa 1167. 1924; Fischer in Gamble, Fl. Madras 3:1431 (1000). 1928; Pull., Fl. Andhra Pradesh 3: 955.1997. (Orchidaceae).

Epiphytic, pendulous herb; pseudobulbs clustered, ovate-cylindrical, $3-5 \mathrm{~cm}$ long. Leaves single, ellipticlanceolate, ca. $28 \times 4 \mathrm{~cm}$, acute at apex, basally 3-nerved, narrowing in to a stout petiole. Inflorescence arise at top of the pseudobulb, pendulous, ca. $45 \mathrm{~cm}$ long. Flowers ca. $3 \mathrm{~mm}$ long, enclosed in persistent floral bracts.

Specimen examined: 116948, 28.ix.2011, (in flowers and fruits), elevation at $1128 \mathrm{~m}$, Minumuluru, Visakhapatnam District, Andhra Pradesh, India, coll. K. Ravikumar \& N. Balachandran.

Distribution: India (Northeastern India, Sikkim and southern India) Nepal, Myanmar, China (Yunnan), Thailand, Laos and Vietnam.

Notes: R.S. Rao collected this species from Gudem Hills in Visakhapatnam District during 1964 (Pullaiah 1997) but Rao \& Kumari (2003) have not included this species in their Flora of Visakhapatnam. During the present study it is seen on the tree trunks of Vitex quinta (Lour.) F.N. Williams at Minumuluru, Paderu Taluk.

Pollia secundiflora (Blume) Bakh. f. in Baker, Beknopte Fl. Java. Afl. X a. Fam. 211, 10 (in clavi). 1949. var. indica (Wight) Sanjappa in Fl. Ind. Enum. Monocot. 30. 1989; Pullaiah, Fl. Andhra Pradesh 3: 1012. 1997. Pollia sorzogonensis (E. Mey) Endl., Gen. 1029.1840; Hook. f., Fl. Brit. India 6: 367. 1892; var. indica (Wight) Hook. f.; Fischer in Gamble, Fl. Madras 3: 1536. 1931. A. indica Wight, Ic, t. 2068. 1853. (Image 18) (Commelinaceae).

Perennial decumbent herb with ascending shoots. Leaves lanceolate or elliptic-oblong, closely spaced below the inflorescence, up to $24 \times 7.5 \mathrm{~cm}$, cuneate at base, acuminate at apex, scabrous above, puberulous below; sheaths tubular, viscid. Inflorescence terminal, thyrsoid panicles, about $25 \mathrm{~cm}$ long, Flowers ca. $8 \mathrm{~mm}$ across; perianth glabrous, clawed, white; bracts persistent. Capsules ellipsoid, ca. $7 \times 5 \mathrm{~mm}$, shining blue; seeds many, finely pitted.

Specimen examined: 110885, 27.ix.2011, (in flowers and fruits), elevation at 560m, Minumuluru, Visakhapatnam District, Andhra Pradesh, India, coll. K. Ravikumar \& N. Balachandran.

Distribution: India (peninsular India), Bhutan, Myanmar, China, Malacca, Sri Lanka and New Guinea.

Notes: In India this species has been recorded from the Deccan Peninsula (Hooker 1872). Gamble (1931) while providing the distribution of this species in southern India quotes the collections of Hohenacker

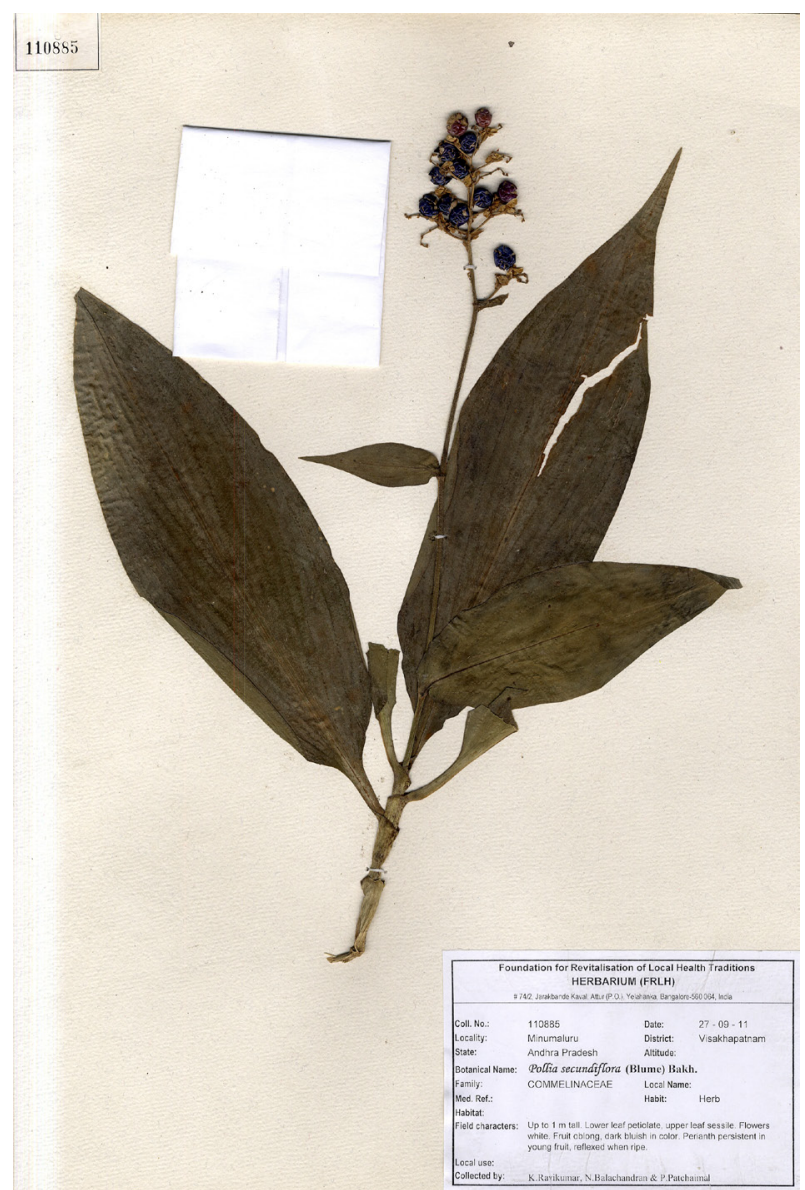

Image 18. Herbarium of Pollia secundiflora

(Coorg), Meebold (S. Canara), Gamble (Wynaad), Beddome (Anamalai \& Tirunelveli) and Narayanaswami (Ethakonda hills in Godavari). Pullaiah (1997) included this taxon based on these earlier collections and Rolla Rao's collection from Gudem Hills in Visakhapatnam District during 1964 (Pullaiah 1997.), but Rao \& Kumari (2003) have not included this species in their Flora of Visakhapatnam District. In the present study about 25 individuals have been counted in an area of $10 \mathrm{~m}^{2}$ and seen growing along a shady and marshy place near a streamlet. This area is often subjected to heavy biotic interference.

Raphistemma pulchellum (Roxb.) Wall., PI. As. Rar. 2:50, Pl. 163. 1831; Hook. f., Fl. Brit. India 4: 19.1883; Brandis, Indian Trees 469. 1906; Kanjilal et al. Fl. Assam 3: 284. 1939; Jagtap \& Singh in Fasc. Fl India 24: 45. 1999. Asclepias pulchella Roxb., Fl. Ind. ed. 1832 2: 54. 1832. (Images 19, 20) (Apocynaceae).

Twining, glabrous shrub; stems branched. Leaves ca. $10 \times 6 \mathrm{~cm}$, broadly ovate, apiculate at apex, cordate 


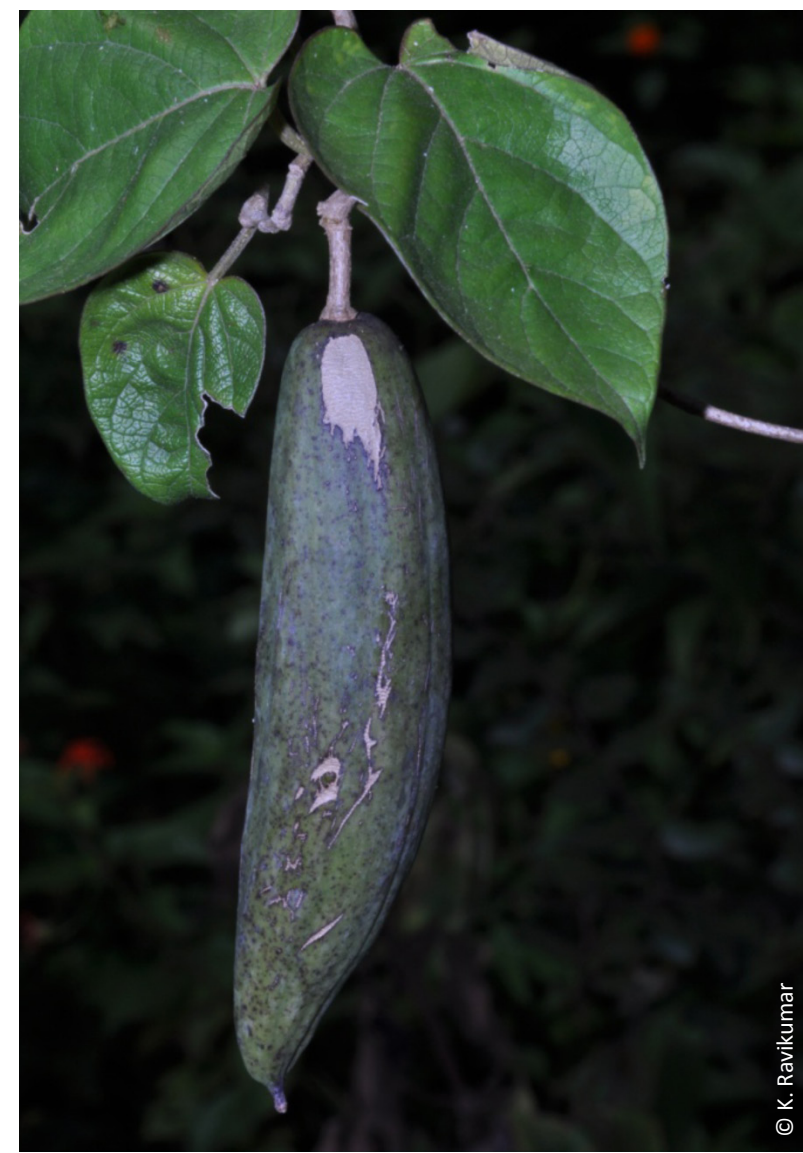

Image 19. Raphistemma pulchellum

with incision 1-2 cm deep at base, basal lobes rounded, glabrous above, sparingly pubescent along the veins beneath; lateral veins 5-7 pairs, lower two arising from the base of mid-vein, arched; petioles terete, $6-7.5 \mathrm{~cm}$ long. Follicle single, ca. $10 \times 2 \mathrm{~cm}$, fusiform, turgid, with a curved beak; seed many, silky white.

Specimen examined: 111312, 27.ix.2011, (in fruits), elevation at $850 \mathrm{~m}$, Minumuluru, Paderu Taluk, Visakhapatnam District, Andhra Pradesh, India, coll. K. Ravikumar \& N. Balachandran.

Distribution: India (Assam, Bihar, Orissa, Sikkim and West Bengal), Java, Nepal.

Notes: In India, this species has so far been recorded from the states of Assam, Sikkim, Bihar, West Bengal and Orissa. The present collection forms a new report for southern India. Only one plant has been seen growing along Antidesma ghasembilla Gaertn., Ardisia solanacea (Poir.) Roxb., Atalantia monophylla DC., Cyclea peltata (Lam.) Hook.f. \& Thomson, Gnetum ula Brongn., Gouania leptostachya DC., Lantana camara L., Tetrastigma sp. and Zanthoxylum armatum DC.

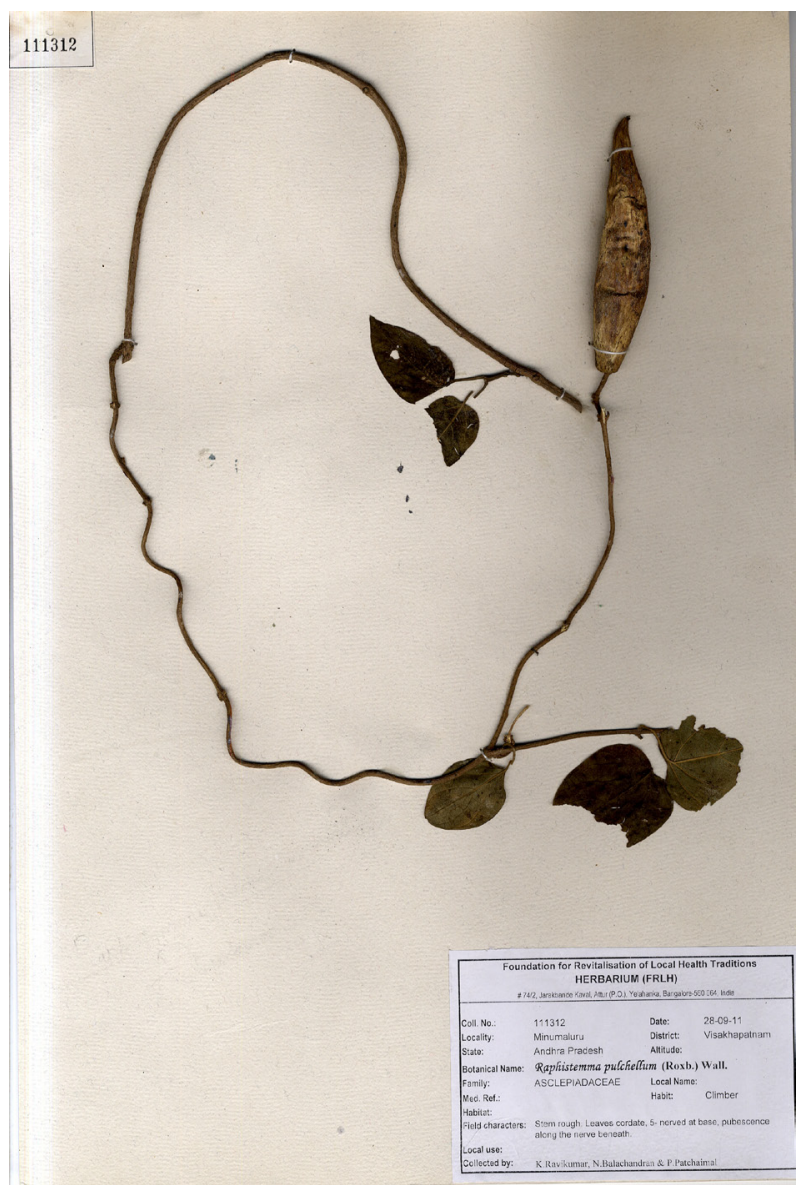

Image 20. Herbarium of Raphistemma pulchellum

Rhamnus nepalensis (Wall.) M.A. Lawson in Hook.f., FI. Brit. India.1: 640. 1875; H.O. Saxena \& Brahmam, Fl. Orissa 1: 312. 1994; Pull. \& Chennaiah, Fl. Andhra Pradesh 1: 204. 1997. Ceanothus nepalensis Wall. in

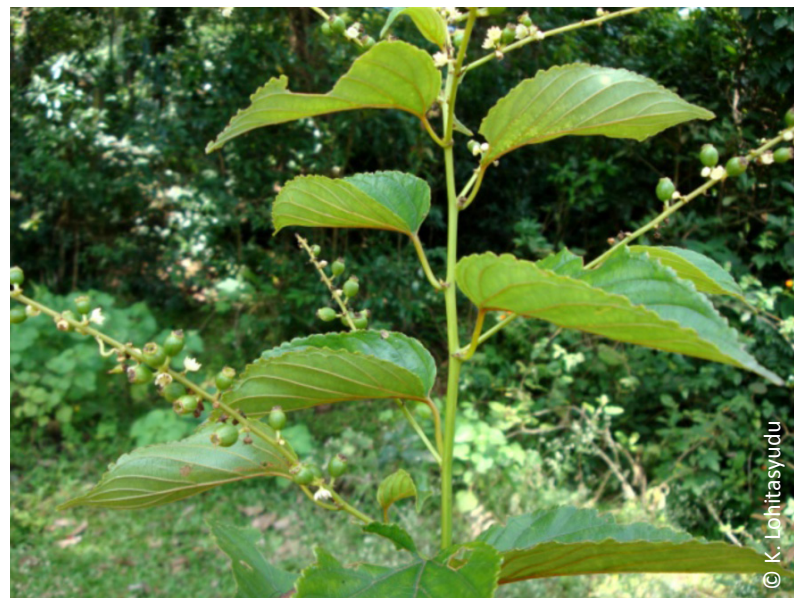

Image 21. Rhamnus nepalensis 
Roxb., FI. Ind. 2: 375. 1824. (Image 21) (Rhamnaceae).

Scandent shrub; branches unarmed, straggling, glabrous on age. Leaves elliptic-oblong, ca. $14 \times 5 \mathrm{~cm}$, obtuse at base, shortly acuminate at apex, distantly crenate-serrate along margins, sub-coriaceous, glabrous; lateral nerves about seven pairs; petioles about $2 \mathrm{~cm}$ long. Inflorescence an axillary clustered raceme, ca. 15 $\mathrm{cm}$ long; flowers cream, ca. $5 \mathrm{~mm}$ across. Drupes ovoid, ca. $6 \mathrm{~mm}$ long, glabrous.

Specimen examined: 116949, 27.ix.2011, (in flowers and fruits), elevation at $1130 \mathrm{~m}$, Minumuluru, Paderu Taluk, Visakhapatnam District, Andhra Pradesh, India, coll. K. Ravikumar \& N. Balachandran.

Distribution: India (Andhra Pradesh, Assam, Bihar, Orissa and West Bengal), Nepal, Myanmar, Malaysia and China.

Notes: In India, this species has been reported from the moist forests up to $1350 \mathrm{~m}$ altitude in the Central and Eastern Himalayan states and Bihar, Orissa, West Bengal and Andhra Pradesh. Gamble (1925) reported it from Mahendragiri Hill in Ganjam, Orissa at 1,500m and Madgol Hills of Visakhapatnam at $1000 \mathrm{~m}$. Pullaiah \& Chennaiah (1997) stated that "not even a single specimen is found in CAL, MH and DD from Andhra Pradesh". This indicates the rarity of this species and therefore the present collection forms an important contribution to Visakhapatnam District.

Only two plants have been noticed in this area and are found associated with species like Gnetum ula Brongn., Gouania leptostachya DC., Cardiospermum halicacabum L. and Zanthoxylum armatum DC. This plant looks very similar to Gouania leptostachya DC. by its habit, branching pattern, phyllotaxy, shape and size of the leaves, inflorescence pattern but can be differentiated only by its un-winged drupes.

Senna sophera (L.) Roxb., Fl. Ind. 2: 347. 1832 (as "sophora"); Larsen \& Hou in Hou et al. Fl. Males. 12(2): 686. 1996; Singh, Monogr.Ind. Subtr. Cassiinae (Caesalpiniaceae), 199. 2001. Cassia sophera L., Sp. PI. 379. 1753; Pull. \& Chennaiah, Fl. Andhra Pradesh 1: 204. 1997. (Image 22) (Fabaceae-Caesalpinioideae).

Shrub, up to $2 \mathrm{~m}$ high. Leaves up to $20 \mathrm{~cm}$ long; leaflets 5-9 pairs, ovate or elliptic-lanceolate, sparsely pubescent; petiole glands single. Inflorescence axillary corymb; flowers ca. $2 \mathrm{~cm}$ across; fertile stamens 7 .

Specimen examined: 111384, 30.ix.2011, (in flower), elevation at 550m, Rompulu Ghat Road (PedavalasaRinthada route), Visakhapatnam District, Andhra Pradesh, India, coll. K. Ravikumar \& N. Balachandran.

Distribution: India (Arunachal Pradesh, Goa, Gujarat,

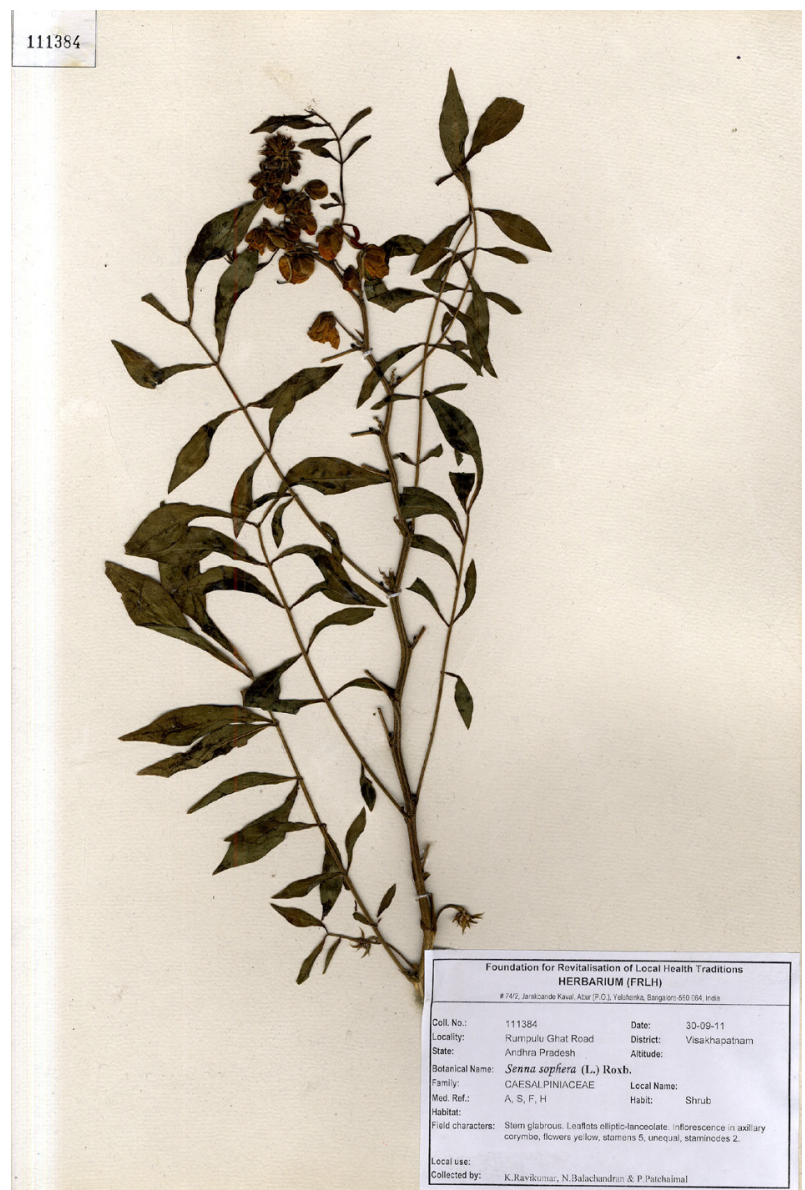

Image 22. Herbarium of Senna sophera

Jammu Kashmir, Kerala, Rajasthan, Sikkim, Tamil Nadu, Tripura, and Andaman \& Nicobar Islands), Pakistan, Nepal, Bhutan, Sri Lanka, China, Malysia, Indonesia, Philippines, Africa and America; cultivated in many other countries.

Notes: Pullaiah \& Chennaiah (1997) state that this species is "common in all plain districts, by road sides and on waste lands", but Flora of Visakhapatnam District has no record of its presence, hence this is a new addition to the district.

Sloanea sterculiacea (Benth.) Rehder \& Wilson in Sarg., PI. Wilson. 2:362. 1915, p.p.; Murti in Sharma \& Sanjappa, FI India 3: 566. 1993; Pull. \& Chennaiah, FI. Andhra Pradesh 1: 160. 1997; Subba Rao \& Kumari, FI. Visakhapatnam 1: 120.2003. Echinocarpus sterculiaceus Benth. in J. Linn. Soc. 5 (Suppl. 2): 72. 1861; Masters in Hook.f., Fl. Brit. India 1: 400. 1874. (Images 23-26) (Elaeocarpaceae).

Deciduous trees, up to $20 \mathrm{~m}$ tall; trunk buttressed; bark smooth, brown, thick, with lichen patches 

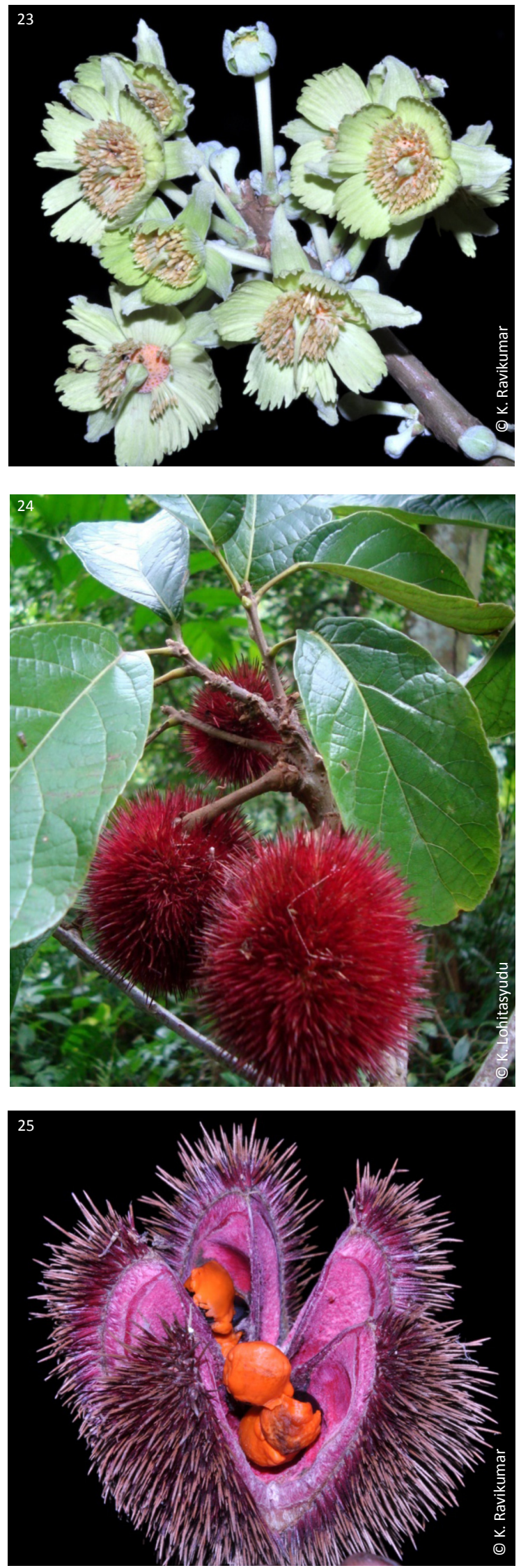

Images 23-25. Sloanea sterculiacea

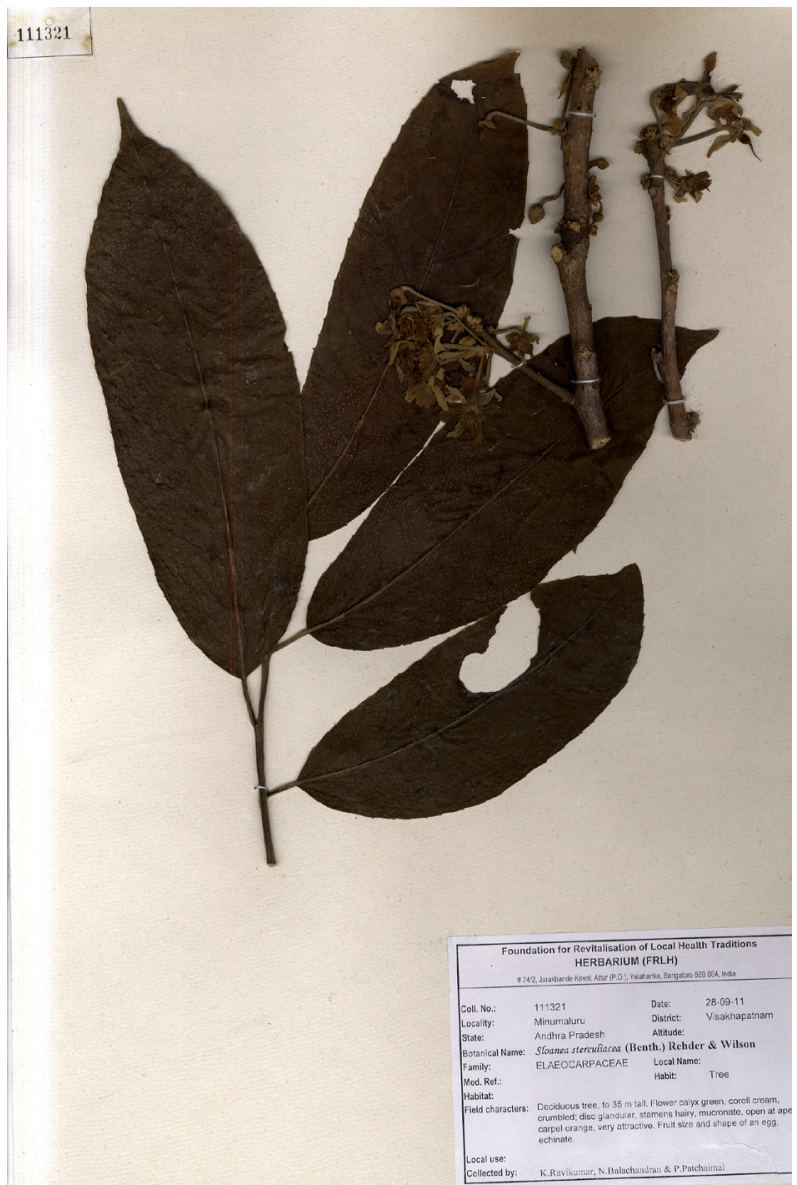

Image 26. Herbarium of Sloanea sterculiacea

throughout branchlets puberulous. Leaves elliptic to oblong-oblanceolate, up to $25 \times 8.5 \mathrm{~cm}$, cuneate-rounded at base, acuminate at apex, glabrous, pubescent along main nerve above; Inflorescence a fascicles arising on leafless parts, tomentose; flowers ca. $3 \mathrm{~cm}$ across, greenish yellow; petals fringed, glandular disc at throat, orange; stamens many, densely hairy, mucronate. Capsules ovoid to globose, ca. $6 \mathrm{~cm}$ across, covered with numerous stiff spines. Seeds 4 , black, shiny, with orange-yellow aril.

Specimen examined: 111321, 28.ix.2011, (in flower and fruit), at $1128 \mathrm{~m}$, Minumuluru, Visakhapatnam District, Andhra Pradesh, India, coll. K. Ravikumar \& N. Balachandran.

Distribution: India (Uttar Pradesh, West Bengal, Sikkim, Assam, Meghalaya and Manipur), Nepal, Bhutan, Bangladesh, Myanmar and China (Yunnan).

Notes: Murti (1993) while providing the distribution of this species in India mentioned the states namely Uttar Pradesh (Kumaon, presently in Uttrakhand), Sikkim and Assam. However, it has been later reported from 
Visakhapatnam District by Pullaiah \& Chennaiah (1997) and Rao \& Kumari (2003). The disjunctive occurrence of this relict species in the Eastern Ghats is quite interesting. Along the side of a stream one matured tree about $1.5 \mathrm{~m}$ gbh and a young one (about $7 \mathrm{~m}$ tall and about $30 \mathrm{~cm}$ gbh) have been noticed. This location faces a serious threat from biotic pressures, therefore an immediate conservation measure is warranted.

\section{References}

Deb, D.B. \& M. Gangopadhaya (1991). Taxonomic study of the genus Lasianthus Jack (Rubiaceae) in India. Journal of Economic and Taxonomic Botany 15(2): 265-308.

Gamble, J.S. \& C.E.C. Fischer (1915-1936). Flora of the Presidency of Madras, Parts $1-11$ (parts $1-7$ by Gamble and 8-11 by Fischer) Adlard \& Sons Ltd., London, 1-2017pp.

Hajra, P.K. \& P.S.N. Rao (eds.) (1999). Flora of Great Nicobar Island. Botanical Survey of India, Calcutta, 438pp.

Hooker, J.D. (eds.) (1872-1897). Flora of British India: Vols. 1-7. Reeve \& Co., London, (vol.i - 740pp; vol.ii - 792pp; vol.iii - 712pp; vol.iv 780pp; vol.v - 910pp; vol.vi - 792pp; vol.vii - 842pp).
Pullaiah, T. \& E. Chennaiah (1997). Flora of Andhra Pradesh: Volume 1. Scientific Publishers, Jodhpur, 463pp.

Pullaiah, T. (1997). Flora of Andhra Pradesh: Volume 3. Scientific Publishers, Jodhpur, 922-1349pp.

Pullaiah, T. \& D.A. Moulali (1997). Flora of Andhra Pradesh: Volume 2. Scientific Publishers, Jodhpur, 464-921pp.

Ramamurthy, K. (2000). Celastraceae, pp. 75-137. In: Singh, N.P., J.N. Vohra, P.K. Hajra \& D.K. Singh (eds.). Flora of India - Vol. 5. Botanical Survey of India, Calcutta.

Rao, G.V.S. \& G.R. Kumari (2003). Flora of Visakhapatnam District, Andhra Pradesh - Volume 1. Botanical Survey of India, India. Ministry of Environment and Forests, Kolkata, 612pp.

Rao, G.V.S. \& G.R. Kumari (2008). Flora of Visakhapatnam District, Andhra Pradesh - Volume 2. Botanical Survey of India, India. Ministry of Environment and Forests, Kolkata, 536pp.

Rao, R.S., S. Sudhakar \& P. Venkanna (1999). Flora of East Godavari District. Indian National Trust for Art and Cultural Heritage (INTACH, New Delhi), Andhra Pradesh State Chapter, Hyderabad, 1-947pp.

Ravikumar, K. \& D.K. Ved (2000). Illustrated Field Guide to 100 Redlisted Medicinal Plants of Conservation Concern in Southern India. Foundation for Revitalisation of Local Health Traditions, Bangalore, 467pp.

Saxena, H.O. \& M. Brahmam (1994). Flora of Orissa - Volume 1-4 (1994-1996). Orissa Forest Development Corporation Ltd., Bhubaneswar, 1-2918pp. 